Sign Systems Studies 33.1, 2005

\title{
On the semiosphere
}

\author{
Juri Lotman \\ Translated by Wilma Clark ${ }^{1}$
}

\begin{abstract}
This article, first published in Russian in 1984 in Sign Systems Studies, introduces the concept of semiosphere and describes its principal attributes. Semiosphere is the semiotic space, outside of which semiosis cannot exist. The ensemble of semiotic formations functionally precedes the singular isolated language and becomes a condition for the existence of the latter. Without the semiosphere, language not only does not function, it does not exist. The division between the core and the periphery is a law of the internal organisation of the semiosphere. There exists boundary between the semiosphere and the non- or extra-semiotic space that surrounds it. The semiotic border is represented by the sum of bilingual translatable "filters", passing through which the text is translated into another language (or languages), situated outside the given semiosphere. The levels of the semiosphere comprise an inter-connected group of semiospheres, each of them being simultaneously both participant in the dialogue (as part of the semiosphere) and the space of dialogue (the semiosphere as a whole).
\end{abstract}

Contemporary semiotics is undergoing a review of some of its basic concepts. It is a well-known fact that at the heart of semiotics lie two scientific traditions. One of these goes back to Peirce-Morris and begins with an understanding of the sign as the first element of any semiotic system. The second is based on the theses of Saussure and the Prague school and has at its core the antinomy of language and speech (texts). However, despite the differences of these approaches,

\footnotetext{
1 [Translator's note.] This article, regarded as a classic or seminal piece by many who have studied Lotman's work, was first published in 1984 in Signs Systems Studies (Труды по знаковым системам) 17: 5-23, and includes one of the first mentioning of the term 'semiosphere' coined by Lotman. Translated from the original Russian language version, published in Lotman 1992. We are not informed about any earlier English translation of this article. (See also fn. 6.)
} 
they share one important commonality: they are based on a simple, atomic element, and everything that follows is considered from the point of view of its similarity to this. Thus, in the first instance, the isolated sign is analysed, and all subsequent semiotic phenomena are considered as a succession of signs. The second point of view, in particular, is expressed by the urge to consider a single communicative act - an exchange of communication between addressee and addressor - as the prime element and model of any given semiotic act. As a result, the individual act of sign exchange has come to be regarded as a model of natural language, and models of natural languages - as universal semiotic models, whereas semiotics itself has sought to be understood as the extension of linguistic methods to objects not included in traditional linguistics. This approach, originating with Saussure, was expressed with maximum clarity by the late I. I. Revzin who, during discussions at the second Summer school on secondary modelling systems in Kääriku (1966), proposed the following definition: The subject of semiotics is any object, which acts as a means of linguistic description.

Such an approach adheres to the well-known rule of scientific thinking: the movement from the simple to the complex — implicitly justifying oneself at the first opportunity. However, in this there is also the danger that heuristic expediency (the convenience of analysis) comes to be accepted as the ontological character of the object, which is assigned to it by the structure derived from the simple and clearly outlined atomistic elements, in accordance with their complexity. The complex object is thus reduced to the totality of the simple.

Over the last 25 years the path of semiotic research has permitted many alternative approaches to emerge. It may now be possible to suggest that, in reality, clear and functionally mono-semantic systems do not exist in isolation. Their articulation is conditioned by heuristic necessity. Neither, taken individually, is in fact, effective. They function only by being immersed in a specific semiotic continuum, which is filled with multi-variant semiotic models situated at a range of hierarchical levels.

Such a continuum we, by analogy with the concept of "biosphere" introduced by V. I. Vernadsky, will call the 'semiosphere'. We must, however, warn against any confusion between the term "noosphere" used by V. I. Vernadsky and the concept of "semiosphere" here introduced. The noosphere - is a specific stage in the development of 
the biosphere, a stage connected with human rational activity. Vernadsky's biosphere is a cosmic mechanism, which occupies a specific structural place in planetary unity. Situated on the surface of our planet and including within itself the totality of living things, the biosphere transforms the radiated energy of the sun into the chemical and physical, and is concerned with the transformation of the inert inanimate materials of our planet, the noosphere occurs when human rational activity acquires a dominant role in this process. ${ }^{2}$ If the noosphere represents the three-dimensional material space that covers a part of our planet, then the space of the semiosphere carries an abstract character. This, however, is by no means to suggest that the concept of space is used, here, in a metaphorical sense. We have in mind a specific sphere, possessing signs, which are assigned to the enclosed space. Only within such a space is it possible for communicative processes and the creation of new information to be realised.

V. I. Vernadsky's understanding of the nature of the biosphere may be useful for defining the concept introduced by us, let us, therefore, look at this in more detail. V. I. Vernadsky defined the biosphere as a space, filled with living matter. "Living matter" - he wrote, — "is the totality of living organisms" (Vernadsky 1967: 350). It would seem that such a definition provides a basis for the supposition that, on this basis, we may take the atomic fact of a single living organism, the totality of which represents the biosphere. However, in reality, this is not so. The fact is that the living matter is already considered as an organic unity - a film on the surface of the planet - and the multiplicity of its internal organisation is displaced at a second level by the unity of the cosmic function - to become a mechanism of the transformation of energy, received from the sun, into the chemicalphysical energy of the earth, - which, according to Vernadsky, reveals the primacy of the biosphere relative to the individual organism.

All these aggregates of life are intimately connected. One cannot exist without the other. This connection between the variety of living films and aggregates and their constant nature is a well-known feature of the mechanism of the earth's crust, occurring throughout many geological periods. (Vernadsky 1960: 101)

2 "The history of scientific thought, of scientific knowledge [...] is simultaneously the history of the creation of a new geological force in the biosphere prior to this scientific thought did not exist in the biosphere" (Vernadsky 1977: 22). 
More specifically, this idea is expressed in the following formula:

The biosphere - consists of a quite definite structure, defining everything, without exception, which falls within it [...]. A thinking being, as he exists in nature, as do all living organisms, as does all living matter, is a function of the biosphere, in its definition of the spatial-temporal. (Vernadsky 1977: 32)

An analogous approach to semiotic questions is also possible. The semiotic universe may be regarded as the totality of individual texts and isolated languages as they relate to each other. In this case, all structures will look as if they are constructed out of individual bricks. However, it is more useful to establish a contrasting view: all semiotic space may be regarded as a unified mechanism (if not organism). In this case, primacy does not lie in one or another sign, but in the "greater system", namely the semiosphere. The semiosphere is that same semiotic space, outside of which semiosis itself cannot exist.

Just as, by sticking together individual steaks, we don't obtain a calf, but by cutting up a calf, we may obtain steaks, - in summarizing separate semiotic acts, we don't obtain a semiotic universe. On the contrary, only the existence of such a universe - the semiosphere makes the specific signatory act real.

The semiosphere is characterized by a range of attributes.

\section{The existence of boundary}

The concept of semiosphere is linked to a definite semiotic homogeneity and individuality. Both these concepts (homogeneity and individuality), as we shall see, are difficult to define formally and depend on systems of description, but this does not change their reality and positive activity on the intuitive level. Both these concepts imply a boundary between the semiosphere and the non- or extra-semiotic space that surrounds it.

One of the fundamental concepts of semiotic delimitation lies in the notion of boundary. Insofar as the space of the semiosphere has an abstract character, its boundary cannot be visualised by means of the concrete imagination. Just as in mathematics the border represents a multiplicity of points, belonging simultaneously to both the internal and external space, the semiotic border is represented by the sum of bilingual translatable "filters", passing through which the text is 
translated into another language (or languages), situated outside the given semiosphere. "The isolated nature" of the semiosphere subsists in the fact that it cannot be contiguous to extra-semiotic texts or nontexts. In order that these may be realised, they must be translated into one of the languages of its internal space, in other words, the facts must be semioticized. In this way, the border points of the semiosphere may be likened to sensory receptors, which transfer external stimuli into the language of our nervous system, or a unit of translation, which adapts the external actor to a given semiotic sphere.

From the aforesaid, it is clear that the notion of boundary correlates to the concept of semiotic individuality. In this respect, we may say that the semiosphere has a "semiotic personality" and combines within this property of personality both the empirically indisputable and intuitive manifestation of the concept and the difficulty of its formal definition. It is a given that the boundary of personality, as a phenomenon of cultural-historical semiotics, depends on the method of coding. Thus, for example, wife, children, dependent servants, vassals may in one system be included in the personality of man, master and patron, without independent individuality, and in others - may appear like separate personalities. This is clearly revealed in the relativity of juridical semiotics. When Ivan the Terrible executed, together with the fallen boyars, not only his family, but all his servants, this was a product not of fear (as if a slave from the provincial patrimony might be a danger to a tsar!), but rather to the fact that, legally, they all belonged to one head and house and, consequently, the execution naturally extended to them.

For the Russian people, the "Terror" - the cruelty of a tsar which lay in the wide application of execution to his people, together with the fact that amongst their number were representatives from all strata of the population, was for them natural. Foreigners, however, were revolted by the fact that the guilt of one man could cause another to suffer. As early as 1732 the wife of the English Ambassador, Lady Rondo (who was not exactly hostile to the Russian court and wrote in her letters of the friendship and sensitivity of Anna Ioanovna and the dignity of Biron) when reporting on the exile of the Dolgoruki family in her European correspondence, wrote: "You may be surprised at the exile of women and children; but here, when the head of the family falls into disgrace, then the whole family is subject to persecution" (Shubinskij 1874: 46). This concept of the collective (in this case - 
patrimonial), and the non-individual personality lies, for example, in the concept of the blood vendetta, where the killer's relatives are regarded as a legally responsible person. S. M. Solovev convincingly connected this practice with the establishment of the collective patrimonial personality:

It is understood, that through such strong patrimonial unity, through such responsibility of all members of a race one towards the other, the meaning of the individual person has necessarily disappeared in the face of the meaning of the race; a single person would be unthinkable without a race; the famous Ivan Petrov was not thought of as a singular Ivan Petrov, but was thought of only in the sense of Ivan Petrov and his brothers and nephews. Through such linkages of person and race, as is raised a singular person - so is raised an entire race, as through the abasement of a single member of the race - so the whole race is abased. (Solovev 1960: 679)

The border of semiotic space is the most important functional and structural position, giving substance to its semiotic mechanism. The border is a bilingual mechanism, translating external communications into the internal language of the semiosphere and vice versa. Thus, only with the help of the boundary is the semiosphere able to establish contact with non-semiotic and extra-semiotic spaces. As soon as we move into the realm of semantics, we have to appeal to an extrasemiotic reality. However, let us not forget, that this reality becomes for a given semiosphere "a reality in itself" only insofar as it has been translated into the language of the semiosphere (in the same way that external chemical materials may be adopted by a cell only if they have been transformed into the internal biochemical structures characteristic of it: in both cases - these are particular manifestations of one and the same law).

The function of any border or film - from the membrane of a living cell to the biosphere as a film (according to Vernadsky) covering our planet, to the delimitation of the semiosphere - comes down to a limitation of penetration, filtering and the transformative processing of the external to the internal. At different levels this invariant function is manifested in a variety of ways. At the level of the semiosphere it represents the division of self from other, the filtration of external communications and the translation thereof into its own language, as well as the transformation of external non-communication into communications, i.e. the semiotization of incoming materials and the transformation of the latter into information. 
From this point of view, all mechanisms of translation, serving external contacts, lie within the structure of the semiosphere.

In instances where cultural space has a territorial character, the border is spatially located in elementary meanings. However, even in this instance, the border retains the idea of a buffer mechanism, a unique unit of translation, transforming information.

So, for example, when the semiosphere identifies itself with the assimilated "cultural" space, and the world which is external to itself with the realm of chaotic disorganised elements - then the spatial distribution of semiotic forms takes the following shape in a variety of cases: a person who, by virtue of particular talent (magicians) or type of employment (blacksmith, miller, executioner), belongs to two worlds, operates as a kind of interpreter, settling in the territorial periphery, on the boundary of cultural and mythological space, whilst the sanctuary of "culture" confines itself to the deified world situated at the centre. In the early years of 19th century culture, the "destructive" zone on the outskirts lay in direct contrast with the town centre, which embodied the dominant social structure, outskirts described, for example, in Tsvetaeva's poem ("Frontier Post") as part of the town, and yet belonging to that place, which destroyed the town. Its nature is bilingual.

All great empires, bordered by nomads, whether "steppe" or "barbarians", settled on their borders members of those same tribes of nomads or "barbarians", hiring them to protect the borders. These settlers formed a zone of cultural bilingualism, ensuring semiotic contacts between two worlds. Areas of multiple cultural meanings carry out the very same function on the boundaries of the semiosphere: town, trade route and other areas forming a kind of creolisation of semiotic structures.

A typical boundary mechanism is that of the "frontier novel" of the type of the Byzantine epic about Digenis or that which alludes to "The Tale of Igor's Campaign". Generally speaking, a subject such as "Romeo and Juliet", about a loving union, connecting two hostile cultural spaces, clearly reveals the essence of the "boundary mechanism".

However, what must also be taken into account is that if (from the point of view of an immanent mechanism) the boundary unites two spheres of semiosis, then from the point of view of semiotic selfknowledge (self-description on a metalevel) in a given semiosphere, it divides them. To realise itself in a cultural-semiotic sense means a 
realisation of its specific character, in terms of its opposition to other spheres. This serves to accentuate absolutely those features by which a given sphere is outlined.

At different historical moments in the development of the semiosphere, one or other aspect may dominate, suppressing or fully neutralising the other.

The boundary has another function in the semiosphere: it is the area of accelerated semiotic processes, which always flow more actively on the periphery of cultural environments, seeking to affix them to the core structures, with a view to displacing them.

For example, the history of ancient Rome illustrates well a more general conformity to natural laws: a cultural area, growing rapidly, incorporates into its orbit external collectives (structures) and transforms them into its own periphery. This stimulates strong culturalsemiotic and economic growth of the periphery, which translates its semiotic structures through to the centre, setting cultural precedents and, in the long run, literally conquers the cultural sphere of the centre. This, in turn, stimulates (as a rule, under the slogan: back "to basics") the semiotic development of the cultural nucleus, in which new structures - linked to the path of historical development - are already visible, but which hides itself in the meta-categories of old structures. The opposition of centre/periphery is replaced by the opposition of yesterday/today. ${ }^{3}$

Insofar as the border is a necessary part of the semiosphere, the semiosphere also requires a "chaotic" external sphere and constructs this itself in cases where this does not exist. Culture not only creates its internal organisation, but also its own type of external disorganisation. Antiquity constructs its "barbarians", and "consciousness" "subconsciousness". It is irrelevant that these "barbarians", firstly, might possess a significantly more ancient culture, or secondly, (not having established a unitary whole) that they might form a cultural gamut ranging from the high civilisations of antiquity to tribes in hugely primitive stages of development. Nevertheless, antique civilisation may only regard itself as culturally intact through the construction of this allegedly unitary "barbarian" world, the main sign of which was the lack of a common language with the culture of antique

3 [Translator's note.] This whole paragraph is missing in Lotman 1992, but exists in the first publication (Lotman 1984). 
civilisation. External structures, distributed on that side of the semiotic boundary, are presumed to be non-structures.

An appreciation of internal and external space is not fixed. The very fact of the presence of a boundary is significant. Thus, in the Robinsoniads of the early 18th century the world of "savages" existing outside of the semiotics of the civilised world was valued positively. A similar situation is found with the artificially constructed worlds of animals or children - which are located outside of the "conventionalities" of culture, that is, of its semiotic mechanisms.

\section{Semiotic irregularity}

From the aforesaid, it is clear that "non-semiotic" space may actually occur within the space of other semiotics. Thus, from an internal point of view, a given culture can look like the external non-semiotic world, which, from the point of view of the external observer, may establish itself as a semiotic periphery. In this way, the crossing point of the boundary of a given culture depends upon the position of the observer.

This question is made more complicated due to the inherited internal irregularity which is a rule of the organisation of the semiosphere. Semiotic space is characterised by the presence of nuclear structures (frequently multiple) and a visibly organised more amorphous semiotic world gravitating towards the periphery, in which nuclear structures are immersed. If one of these nuclear structures not only holds a dominant position, but also rises to a state of self-description, thereby separating itself from the system of meta-languages, with the help of which it describes not only itself but also the peripheral space of a given semiosphere, then the level of its ideal unity creates a superstructure which itself is above the irregularity of a real semiotic map. The active interaction between these levels becomes one of the roots of the dynamic processes within the semiosphere.

Irregularity on one structural level increases the fusion of levels. In the reality of the semiosphere, the hierarchy of languages and texts, as a rule, is disturbed: and these elements collide as though they coexisted on the same level. Texts appear to be immersed in languages which do not correspond to them, and codes for deciphering them may be completely absent. Imagine a room in a museum, where exhibits from different eras are laid out in different windows, with texts in 
known and unknown languages, and instructions for deciphering them, together with explanatory texts for the exhibitions created by guides who map the necessary routes and rules of behaviour for visitors. If we place into that room still more visitors, with their own semiotic worlds, then we will begin to obtain something resembling a picture of the semiosphere.

The structural heterogeneity of semiotic space creates reserves of dynamic processes and represents one of the mechanisms for the creation of new information inside the sphere. In peripheral areas, where structures are "slippery", less organised and more flexible, the dynamic processes meet with less opposition and, consequently, develop more quickly. The creation of meta-structural self-descriptors (grammar) appears to be a factor which dramatically increases the rigidity of the structure and slows down its development. Meanwhile, sections which were not subjected to description, or registered in categories which are clearly inadequate or "at the expense" of grammar, develop quicker. This allows for the future displacement of the function of the structural nucleus to the periphery of the previous stage, and the transformation of the former centre to the periphery. This process can be clearly traced in the geographic transference between the centre and the 'outskirts' of civilised worlds.

The division between the core and the periphery is a law of the internal organisation of the semiosphere. The dominant semiotic systems are located at the core. However, if the fact of such a division is absolute, then the forms in which it takes shape are semiotically relative and are, to a considerable degree, defined by the selected meta-language of description - depending on whether there are elements of self-description (description from the internal point of view and in terms worked out in the process of the self-development of a given semiosphere), or whether this is conducted by an external observer through the categories of another system.

The formation of peripheral semiotics may be represented not by fixed structures (languages) but by their fragments or even separate texts. Falling into the category of "foreigners" within a given system, these texts fulfil the function of a catalyst in the whole mechanism of the semiosphere. On the one hand, the border with foreign texts always appears as an area of enhanced meaning generation. On the other, any fragment of the semiotic structure or separate text preserves the mechanisms for reconstruction of the whole system. Thus the 
destruction of integrity speeds up the accelerated process of "recollection" - reconstructing the semiotic whole through its parts. This reconstruction of language already lost to the system, in which system the given text would have brought meaning, practically always brings the creation of a new language, as opposed to the reconstruction of the old one, as this appears from the point of view of the self-knowledge of culture.

The eternal flow in culture of specific reserves of text with lost codes leads to the process of creation of new codes, often understood subjectively as reconstructions ("recollections").

The structural irregularity of the internal organisation of the semiosphere is determined, in part, by the fact that, having a heterogeneous nature, the semiosphere develops at different speeds and in different places. Different languages belong to different times and different quantitative cycles, thus natural languages develop at a significantly slower pace than mental-ideological structures. Therefore, its processes cannot be synchronous.

In this way, the semiosphere repeatedly traverses the internal borders, assigning a specialized role to its parts in a semiotic sense. The translation of information though these borders, a game between different structures and sub-structures; the continuous semiotic "invasions" to one or other structure in the "other territory" gives birth to meaning, generating new information.

The internal diversity of the semiosphere implies its integrity. Parts enter the whole not as mechanistic details, but as organs in organisms. The essential feature of the structural formation of the core mechanisms of the semiosphere is the fact that each of its parts creates its own whole, isolated in its structural independence. Its connections with other parts are complex and are characterised by a high level of deautomatisation. Moreover, at higher levels, they acquire a behavioural character, i.e. they gain the ability to independently choose programmes of activity. Relative to the whole, located at other levels in the structural hierarchy, they reveal an isomorphic quality. Thus, they are, simultaneously, the whole and its likeness. To clarify this relationship, we may take another example from the end of the 14th century, from the writer Tomasz Štítný. It is also like a face, which, wholly reflected in a mirror, is also reflected in any of its fragments, which, in this form, represents the part and yet remains similar to the whole mirror; so, too, is the integral semiotic mechanism and the 
separate text, relative to the isomorphism of all the texts of the world, and there is a distinct parallelism between individual consciousness, the text and culture as a whole.

Vertical isomorphism, which exists between structures located on different hierarchical levels, generates the quantitative growth of communications. In the same way that an object, reflected in a mirror, generates hundreds of reflections in its fragments, a communication, introduced into the integral semiotic structure, is circulated at the lower levels. The system facilitates the conversion of the text into an avalanche of texts.

However, the transformation of fundamentally new texts requires another mechanism. Here fundamentally different contacts are required. Here, the mechanism of isomorphism is constructed in a different way. Since, here, we don't have in mind a simple act of transfer, but rather an exchange, between participants there must be not only a relationship that is similar, but also one that exhibits a specific difference. A simple condition for this form of semiosis could be outlined as follows: substructures participating in the act of semiosis must not be isomorphic to each other, but separately isomorphic to a third element operating at a higher level of the system which they seek to enter. Thus, for example, the textual and iconic languages of pictorial forms are not isomorphic to each other. But each of them, in a variety of ways, is isomorphic in the extra-semiotic world of reality, which they represent in a given language. On the one hand, this allows for an exchange of communication between these systems and on the other, for the not so trivial transformation of communication and the processes of their transference.

The presence of two similar but simultaneously different partners in communication is one of the most important, but not the only, conditions in which dialogic systems originate. Dialogue includes within itself a reciprocity and mutuality in the exchange of information. But for this, it is necessary that the time of transference be superseded by the time of reception (Newson 1978: 33). And this implies discreteness - the possibility of interrupting the transmission of information. The possibility of giving information in portions appears to be a general law of dialogic systems - from the distribution by dogs of odorous matter in the urine to the exchange of texts in human communication. It should be borne in mind that discreteness can appear at a structural level at a point where, in its material 
realisation, there occurs a cyclic change between periods of high activity and periods of maximal decrease in activity. In fact we might say that the discreteness of semiotic systems is generated by the description of cyclical processes in the language of a discrete structure. Thus, for example, in the history of culture we may delineate periods when one or another form of art, situated at a high point of activity, transmits its texts into other semiotic systems. However, these periods are changed by others when a given type of art as if turns into "receipt". This does not mean that by defining the isolated history of a given type of art we will encounter a break in continuity: studied as immanent, it will appear to be continuous. It is nevertheless worthwhile to set ourselves the goal of describing the whole of art within the framework of a given epoch, as this will clearly reveal the expansion of some and the "interruption", as it were, in the history of others. This may explain still one more phenomenon, well-known to cultural historians, but according to the majority of cultural theories, theoretically non-sensical: such phenomena as the Renaissance, Baroque, Classicism and Romanticism, generated within a given culture by universal factors, must be diagnosed synchronically, against different artistic areas and, indeed, wider still — different intellectual developments.

However, the real history of culture gives quite another picture: the moment of attack of similar epochal phenomena on a variety of different arts only levels out at the metalevel of cultural self-knowledge, crossing over then into research concepts. In the real substance of culture, non-synchronicity does not appear as a sudden deviation, but as a regular rule. At the apogee of its activity, the transferring agent simultaneously produces innovative and dynamic features. The addressees, as a rule, are still experiencing a former cultural stage. There are other, more complex relationships, but such irregularity has the character of universal conformity. Thus, thanks to the constant nature of this conformity (from the immanent point of view) the processes of development from the common cultural position appear discrete.

We might also look at this in terms of the greater natural cultural contacts: the processes of cultural influence of the East on the West and of the West on the East is connected to the non-synchronic sinusoids of their immanent development which, for the external 
observer, establishes a discrete change in their multi-directional activities.

A similar system of relations can also be observed in the diversity of other dialogic systems, for example, between the centre and periphery of cultures, their highs and lows.

The fact that pulsation of activity at the very highest structural level appears to be discrete should not surprise us, if we recall that the boundary between phonemes exists only on the phonological, but by no means at the phonetic level and does not exist in the sonic oscillogram of speech. We may also say the same, relative to other structural boundaries, for example, between words.

Finally, dialogue must possess still another property: insofar as the translated text and the response received from it must produce, from some other third point of view, the unitary text, and through this each of them, from their own point of view, becomes not only a separate text, but has the tendency to become a text in another language; the translated text must, anticipating a response, conserve within itself an element of transference into the other language. Otherwise, dialogue is not possible. John Newson, in the above-cited article showed that, in a dialogue between a nursing mother and her baby, a mutual transition into the language of the other which mimics spoken signals takes place. This dialogue, actually, may be distinguished from one-sided animal-training.

To this is linked, for example, the fact that 19th century literature, in order powerfully influence painting, had to include in its language elements of the picturesque. Analogous phenomena also occur in territorial cultural contacts.

The dialogic (in the wider sense) exchange of texts is not a facultative phenomenon of the semiotic process. The isolated utopia of Robinson Crusoe, a product of 18th century thought, conflicts with the contemporary understanding of consciousness as the exchange of communication: from the exchange between hemispheres of the great brain of man to the exchange between cultures. Meaning without communication is not possible. In this way, we might say, that dialogue precedes language and gives birth to it.

And this also lies at the heart of the notion of semiosphere: the ensemble of semiotic formations precedes (not heuristically but functionally) the singular isolated language and becomes a condition for the existence of the latter. Without the semiosphere, language not 
only does not function, it does not exist. The different substructures of the semiosphere are linked in their interaction and cannot function without the support of each other.

This is the sense of semiosphere in the contemporary world, steadily expanding into space over the centuries, it has now taken on a global character, and includes within itself the call signs of satellites, the verse of poets and the cry of animals. The interdependence of these elements of the semiosphere is not metaphorical, but a reality.

The semiosphere has a diachronic depth, since it is allotted by virtue of a complex memory system without which it cannot function. The mechanism of memory occurs not only in individual semiotic sub-structures, but also in the semiosphere as a whole. Despite the fact that we are immersed in the semiosphere, it can nevertheless establish itself as a chaotic, irregular object, a collection of autonomous elements; it follows, however, that the presence of internally regulated, functionally connected parts can be assumed, the dynamic relationship of which establishes its behaviour. This assumption answers the principle of economy, as, without it, the obvious fact of separate communications would be difficult to explain.

The dynamic development of elements of the semiosphere (substructures) is dictated by their specifications and, consequently, the increase in internal diversity. However, this does not destroy the integrity of the semiosphere, as the basis of all communicative processes lies in the invariant principle, making them similar to each other. This principle is built upon the combination of symmetryasymmetry (at the level of language this structural feature was described by Saussure as the "mechanism of similarities and differences") with the periodic ebb and flow of all vital processes in any of their forms. And these two principles can also be incorporated into a more general unity: symmetry-asymmetry may be regarded as the breaking-up of any form of unity by a plane of symmetry, as a result of which a mirror of the deconstructed structure appears, forming the basis for a subsequent growth in diversity and functional specification. The cyclic recurrence forms the basis of a rotary movement around the axes of symmetry.

The combined effect of these two principles can be observed on very different levels - from the opposition of the cyclic recurrence (of the axis of symmetry) in the world of the cosmos and the atomistic explosion of unidirectional movement, which predominates in the 
animal world and which appears as a result of a plane of symmetry to the antithesis of the mythological (cyclic) and historical (directed) time.

Insofar as the combination of these principles has a structural character, impacting not only on the limits of human society but also the living world, and demands the creation of general structures similar to itself, for example, in poetical works, then the question naturally arises: is the whole universe not a form of communication, falling within an ever more general semiosphere? Is it not destined for a universal reading? It is doubtful whether we were able to find an answer to this question. The possibility of dialogue simultaneously suggests both heterogeneity and homogeneity of elements. Semiotic heterogeneity implies a structural heterogeneity. In this sense, the structural diversity of the semiosphere creates a basis for its mechanisms. In truth, and so conforming to the problem of interest to us, is the following principle, which V. I. Vernadsky called "the principle of P. Curie-Pasteur", may be interpreted as one of "the basic principles of the logic of science - an understanding of nature":

"Dissymmetry may only be drawn out by a cause that itself already possesses dissymmetry." (Vernadsky 1977: 149)

The simplest and most widely disseminated form of combination of a structural identity and difference is enantiomorphism, mirror symmetry, through which both parts of the mirror are equal, but unequal through superposition, i.e. relating one to the other as right and left. Such a relationship creates the kind of correlative difference that distinguishes both identity - rendering dialogue useless — and noncorrelative difference - rendering it impossible. If dialogic communication is the basis of meaning generation, then enantiomorphism divides the unity, and the rapprochement of the difference forms the basis of the structural correlation of individual parts in the construction of meaning generation (Ivanov 1978).

Mirror symmetry creates the necessary relations between structural diversity and structural similarity, which allow dialogic relationships to be built. On the one hand, the systems are not identical and give out diverse texts, and on the other, they are easily converted, ensuring mutual translatability. We may say that, in order for dialogue to take place, the participants must be distinct and yet simultaneously contain within their structure a semiotic image of counter-agent (Paducheva 
1982), and thus enantiomorphism represents the primary "mechanism" of dialogue.

The proof that mirror symmetry can radically change the functionality of the semiotic mechanism, lies in the palindrome. This phenomenon has seen little study, so that - regarded as a piece of poetic fun - the fruit of "the game of word art" (Kvyatkovsky 1966: 190) has, until now, been openly and pejoratively regarded as "juggling words" (Timofeev, Turayev 1974: 257). In the meantime, even a surface examination of this phenomenon reveals very serious problems. We are not interested, here, in the ability of the palindrome to preserve the meaning of a word or a group of words through reading, whether in a straight line or in the opposite direction, but in the fact that, in so doing, the mechanism of textual formation changes and, therefore, also, the mechanisms of consciousness.

Let us recall the analysis of the Chinese palindrome, carried out by the academic, V. M. Alekseev. In declaring that a Chinese hieroglyph, taken in isolation, can only suggest the conceptual family of words, whereas its concrete-semantic and grammatical character are revealed only in correlation to the textual bonds so that, without the order of the word-sign, it is not possible to determine its grammatical category or the real semantic content, which makes concrete the generally abstract semantics of the isolated hieroglyph, V. M. Alekseev reveals the startling grammatical-conceptual displacement, which occurs in the Chinese palindrome, independently of the direction in which it is read. In the Chinese "palindrome" (i.e. a word appearing in normal verse in reverse orientation) all Chinese syllabic words, remaining punctually in their place, are called upon to play other roles, both syntactic and semantic (Alekseev 1951: 95).

From this, V. M. Alekseev drew the methodologically interesting conclusion: that the palindrome represents the best material for studying the grammar of the Chinese language.

The conclusions are clear:

(1) The palindrome represents the best possible means of illustrating the interrelationship of Chinese syllabic words, without resorting to the artificial lecture-theatre style of displacement and unity exercised by students of Chinese syntax, lacking in skill and talent.

(2) The palindrome represent the best Chinese material for the construction of a theory of Chinese (and perhaps not only Chinese) words and simple sentences. (Alekseev 1951: 102) 
An observation of Russian palindromes has brought other conclusions. S. Kirsanov, in a short article, expresses a uniquely interesting reflection on the problem of psychology for the author of Russian palindromes. He notes that, "whilst still a student at the gymnasium" he "involuntarily said of himself":

"Тюлень не лют" [The seal is not fierce] then suddenly realised that this phrase could be read in reverse. From then on I often threw myself into reading words in reverse. [...] With time I was able to see words "as a whole", and such self-rhyming words and their combinations appeared involuntarily. (Kirsanov 1966: 76)

Thus, the mechanism of the Russian palindrome lies in the fact that the word is seen. This then allows it to be read in the reverse order. A very curious thing occurs: in the Chinese language, where the wordhieroglyph seems to hide its morpho-grammatical structure, reading it in the reverse order helps to reveal this hidden construction, displaying the hidden sequential choice of structural elements in a holistic and visible way. In the Russian language, however, the ability to "see the word as a whole" is required, i.e. to receive it in an integrated manner, in its natural hieroglyph. The Chinese palindrome transforms the visible and integral into the discrete and may be analytically differentiated from Russian - which transforms the exact opposite: visibility and integrity. That is to say, reading backwards activates the mechanism of different hemispheric consciousness. It is a primary fact of enantiomorphism that the form of the text changes the type of consciousness attributed to it.

Thus, the perception of the palindrome as a useless "jongleur's tool" or a thoughtless joke resembles the opinion of the rooster in Krylov's fable about the pearl. It is appropriate to recall the moral of this fable:

Fools judge precisely thus:

What they don't understand, they regard as trivial. (Krylov 1946: 51)

The palindrome activates the hidden layers of linguistic meaning and represents exceptionally valuable material for experiments dealing with the problems of functional asymmetry of the brain. The palindro- 
me is not without meaning ${ }^{4}$, but has multiple meanings. At the highest levels the reading in reverse order has been linked to magical, sacred, hidden meanings. The text in its "normal" reading identifies itself with that which is "open", and in its reverse state - with the "esoteric" sphere of culture. The use of palindromes in spells, magical formulas, on the gates of tombs, is significant i.e. its use on the boundaries and magically active places of cultural space - areas where earthly (normal) and infernal (inverse) forces meet. Thus, the authorship of the famous Latin palindrome; which the bishop and poet Apollinaris Sidonius attributed to the devil himself:

Signa te signa, temere me tangis et angis.

Roma tibi subito, motibus ibit amor.

(Cross thyself, you who plague and vex me without need.

For by these words you are about to reach Rome, the object of your desire.)

The mirror mechanism, revealing symmetrical-asymmetrical pairings, is so widespread in all sense-making mechanisms, that you might call it a universal, including the molecular level and general structure of the universe, on the one hand, and a global creation of the human soul, on the other. For phenomena included in the term "text" it is, indisputably, universal. For, parallel to the antithesis of the sacral (direct) and infernal (inverse) structure, its spatial reflectivity is characterised by a convex Purgatory and a concave Hell, the configuration of which, according to Dante is shared between one and the other as form and content. As the subject of a palindromic creation, we may look at the composition "Eugene Onegin" where, in movement in one direction: "she" loves "him", outlining her love in a letter, but receives a cold rebuff, and in a reverse parry "he" loves "her", sending his love in a letter and receives, in his turn, a rebuff. This kind of repetition of the subject is characteristic of Pushkin (Blagoy 1955: 101f). Thus, in "The Captain's Daughter", the subject is composed of two journeys: Grinev's journey to the self-proclaimed "peasants" tsar

4 S. Kalacheva in an article, written from the position of the Krylovian character, comments thus on the Khlebnikov's poem, "Razin": "the value, and sense of words and word combinations ceases to interest the author [...]. The collection of these features is justified only by the fact that it is possible, with an identical measure of success, to read from right to left and from left to right" (Timofeev, Turayev 1974: 441). 
to save Masha and then Masha's journey to the "noblemans" tsarina to save Grinev (Lotman 1962). Analogous mechanisms at the level of the character appear the doubles that inundate the romantic and postromantic literature of 19 th century Europe, frequently connected to the theme of mirrors and reflections.

Of course, all these elements of symmetry-asymmetry are only mechanisms of meaning-making, and like the bilateral asymmetry of the human brain, characterise the mechanism of thought, without predetermining its content; they determine the semiotic situation, but not the content of this or that communication.

Let us give yet one more example of the way in which mirror symmetry changes the nature of the text. N. Tarabukin suggested the rule of pictorial composition, according to which the diagonal axis from the lower right to the upper left corner of a canvas gives the effect of passivity, whereas the inverse - from the lower left to the upper right - is active and intense.

Thus, it is interesting, from an observer's point of view, to consider Jericho's well-known painting "The Raft of Medusa". Its composition is constructed on two interweaving diagonals - the passive and the active. The trajectory of the raft, tossed by the wind, moves from the right to the left and into the depth. It personifies the spontaneous forces of nature, carrying along a handful of helpless people, the victims of a shipwreck. Along the inverse, active line, the artist has placed several human figures, gathering their final strength, so as to extricate themselves from their tragic situation. They have not given up the struggle. High above them is a single individual man, they are helping him to raise the flag, so as to draw the attention of a ship, which has appeared on the distant horizon (Tarabukin 1973: 479).

From this flows an experimentally corroborated fact: that one and the same canvas, transformed into the mirror symmetry of a printed engraving, transforms the emotional-semantic accent to its inverse state.

The reason for these notable phenomena lies in the fact that reflected objects possess their own internal structure of surface symmetry and asymmetry. Through enantiomorphic transformation, surface symmetry is neutralised and cannot be displayed in any other way, and asymmetry becomes the structural signifier. Therefore, mirror-symmetry represents the primary structure for the dialogic relationship. 
The law of mirror symmetry is one of the basic structural principles of the internal organisation of meaning-making constructions. It includes, at the topical level, such parallel phenomena as the "high" or comic character, the appearance of doubles, parallel topicality and other well-known phenomena in the duality of intra-textual structures. Also included in this are the magic function of the mirror and the role of the mirror motif in literature and art. The phenomenon of "texts within texts" also has the very same nature. In this respect, we may even compare a phenomenon examined by us elsewhere, which may be observed at the holistic level of national cultures: the process of mutual acquaintance and inclusion into a specific general cultural world causes not only the rapprochement of separate cultures, but also their specialization - after entering a specific general culture, a given culture begins to cultivate its own originality in a more acute fashion. In its turn, the other culture also considers it as "special", "unique". The isolated culture "to itself" is always "natural" and "usual". Only by taking part in a much greater whole, does it recognise the external point of view as specific to itself. In this way, cultural generalities of the type "West" and "East" are revealed in the enantiomorphic pairings of functional asymmetry.

Since all levels of the semiosphere - from human personality to the individual text to the global semiotic unity - are a seemingly inter-connected group of semiospheres, each of them is simultaneously both participant in the dialogue (as part of the semiosphere) and the space of dialogue (the semiosphere as a whole), in each can be seen manifestations of 'rightism' and 'leftism' and, whether lying to the right or left, each also includes within itself, at the lowest level, structures belonging to both right and left.

Earlier we described the basis of the structural creation of the semiosphere as the intersection of three-dimensional symmetryasymmetry and the sinusoidal change of intensity and attenuation of temporal processes, which generates discreteness. After all is said and done, we can reduce these two axes to one: the development of rightleft; that which, from the genetic-molecular level to the most complex information processes, forms the basis of dialogue - the basis of all meaning-making processes.

See the papers by V. V. Ivanov, P. H. Torop, Yu. I. Levin, R. D. Timenchik, and myself in Text within Text (Sign Systems Studies 14, 1981). 


\section{References}

Alekseev 1951 = Алексеев, Василий. Китайский палиндром в его научнопедагогическом использовании. In: Ларин, Б. А. (ред.), Памяти академика Льва Владимировича Щербы. Ленинград: Изд-во ЛГУ.

Blagoy 1955 = Благой, Дмитрий. Мастерство Пушкина. Москва.

Ivanov 1978 = Иванов, Вячеслав. Чет и нечет: Асимметрия мозга и знаковых систем. Москва: Советское радио.

Kirsanov 1966 = Кирсанов, Семен. Поэзия и палиндром. Наука и жизнь 7: 76. Krylov 1946 = Крылов, Иван. Полное собрание сочинений. Т. 3. Москва.

Kvyatkovsky 1966 = Квятковский, Александр. Поэтический словарь. Москва: Советская энциклопедия.

Lotman 1962 = Лотман, Юрий. Идейная структура "Капитанской дочки". In: Пушикинский сборник. Псков, 3-20.

Newson, John 1978. Dialogue and Development. In: Lock, Andrew (ed.), Action, Gesture and Symbol: The Emergence of Language. London: Academic Press.

Paducheva 1982 = Падучева, Елена. Тема языковой коммуникации в сказках Льюиса Кэрролла. In: Семиотика и информатика 18. Москва: ВИНИТИ.

Shubinskij 1874 = Шубинский, С. (ред.), Письма леди Рондо, жены английского резидента при русском дворе в иарствование имп. Анны Иоановны. Санкт-Петербург: Издание Я. А. Исакова.

Solovev 1960 = Соловьев, Сергей. История России с древнейших времен. Книга 3. Москва: Соцэкгиз.

Tarabukin 1973 = Тарабукин, Николай. Смысловое значение диагональных композиций в живописи. Tpyды по знаковым системам (Sign Systems Studies) 6: 472-481.

Timofeev, Turayev 1974 = Тимофеев, Леонид; Тураев, Сергей (ред.-сост.), Словарь литературоведческих терминов. Москва: Просвещение.

Vernadsky 1960 = Вернадский, Владимир. Избранные сочинения. Т. 5. Москва: Изд-во АН СССР.

- 1967 = Вернадский, Владимир. Избранные труды по биохимии. Москва: Наука.

— 1977 = Вернадский, Владимир. Размышиления натуралиста. Кн. 2. Москва: Наука. 


\section{The publications of this article in Russian ${ }^{6}$}

Lotman 1984 = Лотман, Юрий. О семиосфере. Труды по знаковым системам (Sign Systems Studies) 17: 5-23.

Lotman 1992 = Лотман, Юрий. O семиосфере. In: Лотман, Юрий, Избранные статьи в трех томах. Т. 1. Таллинн: Александра, 11-24.

\section{О семиосфере}

Восходить от простого к сложному - естественный принцип науки. Однако в нем таится и опасность: эвристическая целесообразность (удобство анализа) начинает восприниматься как онтологическое свойство объекта, которому приписывается структура, восходящая от простых и четко очерченных атомарных элементов к постепенному их усложнению. Сложный объект сводится к сумме простых.

Пройденный за последние двадцать пять лет путь семиотических исследований позволяет на многое взглянуть иначе. Как можно теперь предположить, четкие и функционально однозначные системы в реальном функционировании не существуют сами по себе, в изолированном виде. Вычленение их обусловлено лишь эвристической необходимостью. Ни одна из них, взятая отдельно, фактически не работоспособна. Они функционируют, лишь будучи погружены в некий семиотический континуум, заполненный разнотипными и находящимися на разном уровне организации семиотическими образованиями. Такой континуум, по аналогии с введенным В. И. Вернадским понятием “биосфера” мы называем семиосферой.

Семиосфера характеризуется рядом признаков, прежде всего отграниченностью и неравномерностью. Одним из фундаментальных понятий семиотической отграниченности является понятие границы. Поскольку пространство семиосферы имеет абстрактный характер, границу ее не следует представлять себе средствами конкретного воображения. Структурная неравномерность внутренней орга-

$6 \quad$ A German translation (Über die Semiosphäre) has appeared in Studia Russica Helsingiensia et Tartuensia. Helsinki, p. 7-24 (1989); and in Zeitschrift für Semiotik 12(4): 287-305 (1990). There exist also translations of this article into Spanish, into Estonian, etc.

An earlier attempt to translate this article into English in order to publish it in Semiotica has been made in 1986, however, as Thomas Sebeok has described in his memoirs, the process unfortunately failed (see Sign Systems Studies 26: 29-31, 1998). 
низации семиосферы определяется, в частности, тем, что, будучи гетерогенной по природе, она развивается с различной скоростью в различных своих участках. Разные языки имеют различное время и различную величину циклов, так, естественные языки развиваются значительно медленнее, чем ментально-идеологические структуры. Поэтому о синхронности протекающих в них процессов не может быть и речи. Внутреннее разнообразие семиосферы подразумевает ее целостность. Части входят в целое не как механические детали, а как органы в организм. Существенной особенностью структурного построения ядерных механизмов семиосферы является то, что каждая ее часть сама представляет собой целое, замкнутое в своей структурной самостоятельности.

Сознание без коммуникации невозможно. В этом смысле можно сказать, что диалог предшествует языку и порождает его. Именно это и лежит в основе представления о семиосфере: ансамбль семиотических образований предшествует (не эвристически, а функционально) отдельному изолированному языку и является условием существования последнего. Без семиосферы язык не только не работает, но и не существует. Различные субструктуры семиосферы связаны во взаимодействии и не могут работать без опоры друг на друга. Поскольку все уровни семиосферы — от личности человека или отдельного текста до глобальных семиотических единств являют собой как бы вложенные друг в друга семиосферы, каждая из них представляет собой одновременно и участника диалога (часть семиосферы) и пространство диалога (целую семиосферу).

\section{Semiosfäärist}

Liikumine lihtsamalt keerulisemale on teaduses loomulik põhimõte. Ometi peitub temas oht: heuristilist otstarbekohasust (analüüsi hõlpsust) hakatakse tajuma kui objekti ontoloogilist omadust ja objektile omistatakse struktuur, mis lihtsatest ja kindlapiirilistest atomaarsetest elementidest lähtudes järk-järgult areneb nende keerukustumise suunas. Keeruline objekt taandatakse lihtsate summaks.

Viimase kahekümne viie aasta jooksul läbitud semiootikauuringute tee lubab näha paljusid asju teisiti. Nagu nüüd võib oletada, pole kindlapiirilisi ja funktsionaalselt ühetähenduslikke tähendussüsteeme reaalses talitluses omaette ega isoleeritud kujul olemas. Nende väljaliigendamist tingib üksnes heuristiline vajadus. Eraldi võetuna ei ole ükski neist tege- 
likult töövõimeline. Nad toimivad ainult paigutatuna teatavasse semiootilisse kontiinumisse, mis on täidetud eritüübiliste ja erisugusel korrastusastmel semiootiliste moodustistega. Niisugust kontiinumit me nimetame semiosfääriks - analoogia põhjal Vladimir Vernadski poolt tarvitusele võetud "biosfääri" mõistega.

Semiosfääril on rida iseloomulikke tunnuseid, eelkõige piiritletus ja ebaühtlus. Semiootilise piiritletuse üks alusmõisteid on piiri mõiste. Et semiosfääri ruumil on abstraktne iseloom, ei ole vaja tema piiri enesele konkreetse kujutluse abil silma ette manada. Semiosfääri sisekorralduse struktuuriline ebaühtlus on muu hulgas tingitud sellest, et olles loomult heterogeenne, areneb semiosfäär oma eri piirkondades erineva kiirusega. Eri keeltel on erinev aeg ja erisugune tsüklipikkus: loomulikud keeled arenevad märksa aeglasemalt kui mentaal-ideoloogilised struktuurid. Sellepärast ei saa juttugi olla neis kulgevate protsesside sünkroonsusest. Semiosfääri sisemine mitmekesisus peab silmas ta terviklikkust. Osad ei kuulu tervikusse mitte mehaaniliste detailidena, vaid nagu organid organismi. Semiosfääri tuummehhanismide struktuurse ehituse peamine iseärasus on, et iga osa on ise tervik, suletud oma struktuursesse iseseisvusesse.

Teadvus ei ole võimalik ilma kommunikatsioonita. Ses mõttes saab öelda, et dialoog eelneb keelele ja sünnitab keele. Just sellel põhinebki semiosfääri-kujutelm: semiootiliste moodustiste kooslus eelneb (mitte heuristiliselt, vaid funktsionaalselt) üksikule isoleeritud keelele ja on tema olemasolu tingimus. Ilma semiosfäärita keel mitte ainult et ei hakka tööle, vaid teda pole olemaski. Semiosfääri erisugused allstruktuurid on vastastikku seotud ega saa töötada ilma üksteise toeta. Et semiosfääri kõik tasandid - inimisiksusest või üksiktekstist kuni globaalsete semiootiliste ühtsusteni - on justkui üksteise sisse asetatud semiosfäärid, siis on igaüks neist ühtaegu nii dialoogis osaleja (semiosfääri osa) kui ka dialoogi ruum (terve semiosfäär). 